\title{
Teachers' perception of STEM integration and education: a systematic literature review
}

\author{
Kelly C. Margot ${ }^{1 *}$ (D) and Todd Kettler ${ }^{2}$
}

\begin{abstract}
Background: For schools to include quality STEM education, it is important to understand teachers' beliefs and perceptions related to STEM talent development. Teachers, as important persons within a student's talent development, hold prior views and experiences that will influence their STEM instruction. This study attempts to understand what is known about teachers' perceptions of STEM education by examining existing literature.

Results: Study inclusion criteria consisted of empirical articles, which aligned with research questions, published in a scholarly journal between 2000 and 2016 in English. Participants included in primary studies were preK-12 teachers. After quality assessment, 25 articles were included in the analysis. Thematic analysis was used to find themes within the data. Findings indicate that while teachers value STEM education, they reported barriers such as pedagogical challenges, curriculum challenges, structural challenges, concerns about students, concerns about assessments, and lack of teacher support. Teachers felt supports that would improve their effort to implement STEM education included collaboration with peers, quality curriculum, district support, prior experiences, and effective professional development.
\end{abstract}

Conclusions: Recommendations for practice include quality in-service instruction over STEM pedagogy best practices and district support of collaboration time with peer teachers. Recommendations for future research are given.

Keywords: STEM, Teacher perception, Teacher beliefs, Systematic literature review, Engineering in K-12 schools

\section{Introduction}

In order to address the need for more science, technology, engineering, and mathematics (STEM) literate workers, both elementary and secondary classrooms are integrating STEM curriculum and pedagogy into their school day. According to NAE \& NRC (2014), STEM literate means (1) awareness of the roles of science, technology, engineering, and mathematics in modern society; (2) familiarity with at least some of the fundamental concepts from each area; and (3) a basic level of application fluency (e.g., the ability to critically evaluate the science or engineering content in a news report, conduct basic troubleshooting of common technologies, and perform basic mathematical operations relevant to daily life) (p. 34).For every person that is unemployed

\footnotetext{
* Correspondence: margotk@gvsu.edu

${ }^{1}$ Department of Teaching and Learning, Grand Valley State University, 401

Fulton St. W, Grand Rapids, MI 49504, USA

Full list of author information is available at the end of the article
}

with a STEM degree, there are 2.4 million unfilled jobs (National Science Board 2012). It is important to our economy that schools be successful at producing students capable of talented contributions in STEM fields. In order to capitalize fully on the STEM potential of our students, schools must streamline STEM education and refine their instructional pedagogy. Gomez and Albrecht (2013) advocate for grounding this education and instruction in STEM pedagogy through an interdisciplinary approach. This approach allows students to make real-world connections and prepare for STEM pathways and careers. Reform initiatives have begun with the goal of better integrating engineering and technology into traditional math and science classrooms (National Science Board 2007). Teaching through the engineering design process is one approach to integrating the subjects using a project-based approach that requires students to apply content knowledge to solve problems. This is the basis for STEM pedagogy. The students learn by doing 
and are encouraged to develop new understandings while refining their ideas (Mooney and Laubach 2002). Providing in-depth problem solving through STEM education with authentic experiences requires that teachers are skilled with this unique student-directed pedagogy. Educators have to understand the value and power of the engineering design process to enable students to fail and persevere. These teachers have to know not just their subject matter, but the content of the other disciplines. Also, they must feel capable of creating an educational environment that allows students to solve ill-defined problems while deepening their content knowledge.

\section{STEM education and talent development}

Gagné's (2011) differentiated model of giftedness and talent explains how a person's natural abilities, or gifts, can be developed through learning and practice into talents. Part of this model is the presence of catalysts that can either inhibit or facilitate the talent development process. These catalysts can be intrapersonal, like perfectionism or confidence, environmental, like programs or persons, or chance, things like genetic make-up and family. Teachers are an example of persons who play the role of catalyst in the talent development process (Gagné 2007). In this role, they can either help or hinder a student's development of STEM talent. STEM programs are an example of an environmental catalyst. The availability of a quality STEM program in a student's education would facilitate their talent development in science, technology, engineering, and mathematics (MacFarlane 2016). The teacher plays an important role in this environment, and therefore, the person and environment work together to develop STEM talent in this model. Within Gagné's (2011) model, catalysts are not part of the initial gift or the end talent, they are just part of the developmental pathway between the two. During the learning and practice required to develop STEM talent, teachers and STEM programs provide the opportunities, support, and experiences students need to reach their potential (MacFarlane 2016).

STEM education is not a well-defined experience, but it does involve similar hallmarks within the design and implementation (Honey et al. 2014). Moore et al. (2014) conducted an extensive review of published literature, analyzed documents of state content standards, and consulted with experts in STEM fields in order to determine the ways teachers utilize STEM education in their classrooms. After this exhaustive search, these researchers designated a framework that includes six major tenets for quality K-12 STEM education: (a) the inclusion of math and science content, (b) student-centered pedagogy, (c) lessons are situated in engaging and motivating context, (d) inclusion of engineering design or redesign challenge, (e) students learn from making mistakes, and (f) teamwork is emphasized. STEM in education is both a curriculum and pedagogy. The curriculum includes cross-curricular real-world challenges for students to solve. Judith Ramely, who was the director of the National Science Foundation's education and human resources division, decided on the acronym STEM. She explained that math and science are used as the bookends for engineering and technology (Christenson 2011). According to Honey et al. (2014), the integration of knowledge must be explicit both within the disciplines and across the disciplines. Students must have intentional instruction into the connectedness of science, technology, engineering, and mathematics. STEM education also includes the use of the engineering design process. There are various forms of this process, but they all include a cyclical process of students evaluating their solutions and then working to improve upon them. This revision step is an important part of STEM because it requires perseverance and the acknowledgment that solutions can always be improved upon. There is more than one answer to STEM challenges. STEM pedagogy explains the teacher's role within STEM instruction. The teacher guides students to examine problems from all angles by questioning. This pedagogy involves the philosophy that students are capable of guiding their own learning. Teachers are just there to facilitate this student-led process. Students use hands-on, practical applications of content in order to solve their challenges. Students are also introduced to STEM professions, which some researchers believe may increase the number of underrepresented populations in STEM jobs (Bagiati and Evangelou 2015). The student goals of STEM education according to Honey et al. (2014) include STEM literacy, twenty-first century competencies, STEM workforce readiness, ability to make connections among STEM disciplines, and interest and engagement. While addressing the standards in each subject area, students engage in the engineering design process to make connections to the real world. An example is studying simple machines to discover how a car works.

STEM education includes student use of math and science concepts they have learned in an applied setting through the use of engineering design and technology. Instead of being taught in a vacuum, math and science are brought to life through their need to be used in order to solve a real problem (Chamberlin and Pereira 2017).

An example of STEM education in action was a student raising the question about what could be done to prevent a neighborhood raccoon from getting into his family's trashcan. The class analyzed the situation and the trashcan in question then proposed creating a clip for the lid using a 3D printer. The students carefully measured and designed the clip. After printing, they 
discovered the clip would not stay attached to the can. At this point, they evaluated what modifications needed to be made in the design. Using 3D CAD software, the students made the changes and reprinted the trashcan clip. This time the clip worked to keep the lid attached to the trashcan and prevented further raccoon scavenging in his family's trash.

\section{STEM and gifted}

Some of the same tenets of gifted education are seen in STEM pedagogy. Hockett (2009) examined all major curriculum recommendations for gifted learners and found five principles of agreement: uses a conceptual approach within a discipline; pursues advanced levels of understanding; asks students to use processes and materials that approximate those of a practicing professional in the domain; and emphasizes problems, products, and performances that are true-to-life with transformational outcomes, and the curriculum needs to be flexible enough to allow self-directed learning fueled by student interest. STEM pedagogy contains all five principles by allowing students to work as professionals within the disciplines of science, technology, engineering, and math, while solving real-world problems in which they are interested. STEM pedagogy also leads students to a deeper understanding of content while solving ill-defined problems (Mann and Mann 2017).

According to VanTassel-Baska and Little (2011), this type of pedagogy is not only good practice with gifted students, but is also best practice with all students. All students benefit from instruction rich in context and student-led investigations.

Though efforts are being made to implement STEM programming from the government all the way down to local school district initiatives, teachers are the single most important factor in the equation (McMullin and Reeve 2014). Curriculum is simply a blueprint, and STEM education requires a pedagogical shift to student-centered learning. In addition, much of the instruction is inquiry-based and experimental. It is paramount that administrators and policy-makers discover the challenges and barriers teachers believe impede this effort to develop STEM talent in classrooms. It is also salient to discover what supports teachers feel would bolster their work as STEM practitioners. The role of the teacher is different with STEM, but just as important. These teachers have to provide project-based lessons that encourage critical thinking and innovation while building student understanding of content and concepts (Nadelson and Seifert 2013). Teachers must use questioning strategies to challenge students to think using higher cognitive processes so they will think deeply about concepts and ideas in order to solve STEM challenges (Bruce-Davis et al. 2014). This type of questioning is an essential skill for STEM teachers' instruction. How do teachers feel about using this type of questioning with students? Although primary and secondary teachers play an important role in the STEM talent development of these students, few studies exist determining the prior held beliefs and perceptions of these practitioners toward STEM curriculum and pedagogy. Policy-makers, administrators, and school administrators need to understand what challenges and barriers teachers feel exist that prevent them from developing STEM talent in our schools. Johnson (2006) reported that many teachers lack resources needed to effectively implement inquiry-based learning experiences for their students. Understanding these challenges can help facilitate the implementation and success of STEM programs. Both school administrators and teacher educators also need to determine what supports teachers feel would improve their ability to prepare students seeking STEM degrees and pursuing STEM careers.

This review, by examining and critically analyzing multiple existing studies, will provide a complete summary of what is known about teacher beliefs and perceptions regarding STEM curriculum and pedagogy.

\section{Research questions}

The purpose of the study is to examine existing literature on teachers' perceptions of developing STEM talent. This study attempts to understand what is known about teacher beliefs related to STEM talent development. To examine what exists in the literature, the following questions were used:

1) How does existing research characterize teachers' perceptions of utilizing STEM pedagogy?

2) What do teachers identify as challenges and barriers to using STEM pedagogy in their classrooms?

3) What supports do teachers feel would improve their efforts to implement STEM pedagogy in their classrooms?

\section{Methods}

This systematic literature review utilized the PRISMA guidelines and flow chart. PRISMA guidelines include a 27-item checklist and a four-phase flow diagram outlining the items essential for transparency in conducting literature reviews (Liberati et al. 2009).

\section{Eligibility criteria}

In order to be included in this review, studies needed to be peer-reviewed and published in a scholarly journal (trade journals, magazines, and newspapers were excluded) between 2000 and 2017. Eligible studies also needed to be published in English with preK-12 teacher 
participants and empirical in nature (editorials and monographs were excluded). The study also needed to address at least one of the review's research questions.

\section{Data sources}

Databases searched were electronic and concerned the areas of education and social science. The exact databases searched were Academic Search Complete, ERIC via Ebscohost, and PsychINFO via Ebscohost. To be thorough, Google Scholar was also used to check that all relevant articles had been found. Google Scholar does not have the same limiting search terms so yielded 869,000 results sorted by relevance. Haddaway et al.'s (2015) recommendation to examine the first 200 to 300 results from Google Scholar in order to find any missed literature was followed, and the abstracts of the first 300 articles were examined. One article was found that had not been found on the other databases. The last search was run on September 28, 2018.

\section{Search}

The following search terms were used to search each database: "teacher" AND "perception OR beliefs OR attitudes" AND "STEM OR engineering." All searches were made against article abstracts. Search limiters were used to align with the screening criteria. Results of the initial search can be found in Table 1 .

\section{Study selection \\ Screening}

A diagram of the screening process can be seen in Fig. 1. In order to select studies for inclusion the following criteria were used sequentially against article abstracts:

Criteria 1: Study published between 2000 and 2017 in English

Criteria 2: Study published in scholarly journal

Criteria 3: Study participants included preK-12 teachers

Criteria 4: Study is empirical (qualitative, quantitative, mixed methods, or meta-analyses)

Criteria 5: Extracted data aligns with current study's focus and research questions
A total of 29 articles were retained after screening.

\section{Evaluation}

In order to evaluate the quality of each article, a rubric that examined seven criterion (Objectives and Purposes, Review of the Literature, Theoretical Frameworks, Participants, Methods, Results and Conclusions, and Significance) was used against the full-text contents, and each of the seven parts was measured to see that they met the standards of quality reporting (Mullet 2016) (Table 2). Each of the seven parts was scored on a 4-point scale where $1=$ Does Not Meet Standard, 2 = Nearly Meets Standard, 3 = Meets Standard, and $4=$ Exceeds Standard. After summing the seven parts, the total possible score for each article was between 7 and 28. Articles that scored equal to or less than 14 were excluded as not meeting the quality standard. After assessing the quality of each article, four were excluded and 25 retained. To guard against bias, the second author reviewed included and excluded articles against the criteria and confirmed that all retained articles met the criteria.

\section{Data analysis}

Thematic analysis (Braun and Clarke 2006) was used as a method for identifying, analyzing, and reporting themes (or patterns) within the data. Each theme is meant to capture important information about the data. Braun and Clarke (2006) recommend six phases of thematic analysis. The first phase involved becoming familiar with the data, the second phase was where initial codes were generated, the third phase involved an initial search for themes by collating the codes, the fourth phase required that each theme was checked or reviewed to ensure the coded extracts work in relation, the fifth phase was when the themes were defined and named, and the sixth phase was producing the report from the themes by relating them back to the research questions.

To establish a rating protocol, both authors read all 25 retained articles and agreed on a pre-set coding protocol using four broad categories: (a) teachers, (b) district support, (c) curriculum/materials, and (d) students. The first three articles were analyzed independently by both authors, and 45 text segments were extracted and placed

Table 1 Results of initial search

\begin{tabular}{lll}
\hline Search terms & Database & Search limiters \\
\hline "teacher" AND "perception OR beliefs OR attitudes" AND & Academic Search Complete & $\begin{array}{l}\text { Scholarly (peer reviewed) Journals } \\
\text { Published: 2000-2017 }\end{array}$ \\
"STEM OR engineering" & ERIC via Ebscohost & $\begin{array}{l}\text { Scholarly (peer reviewed) Journals } \\
\text { Published: 2000-2017 } \\
\end{array}$ \\
& PsyclNFO via Ebscohost & $\begin{array}{l}\text { Scholarly (peer reviewed) Journals } \\
\text { Published: 2000-2017 }\end{array}$ \\
& Total with duplications removed & \\
712
\end{tabular}




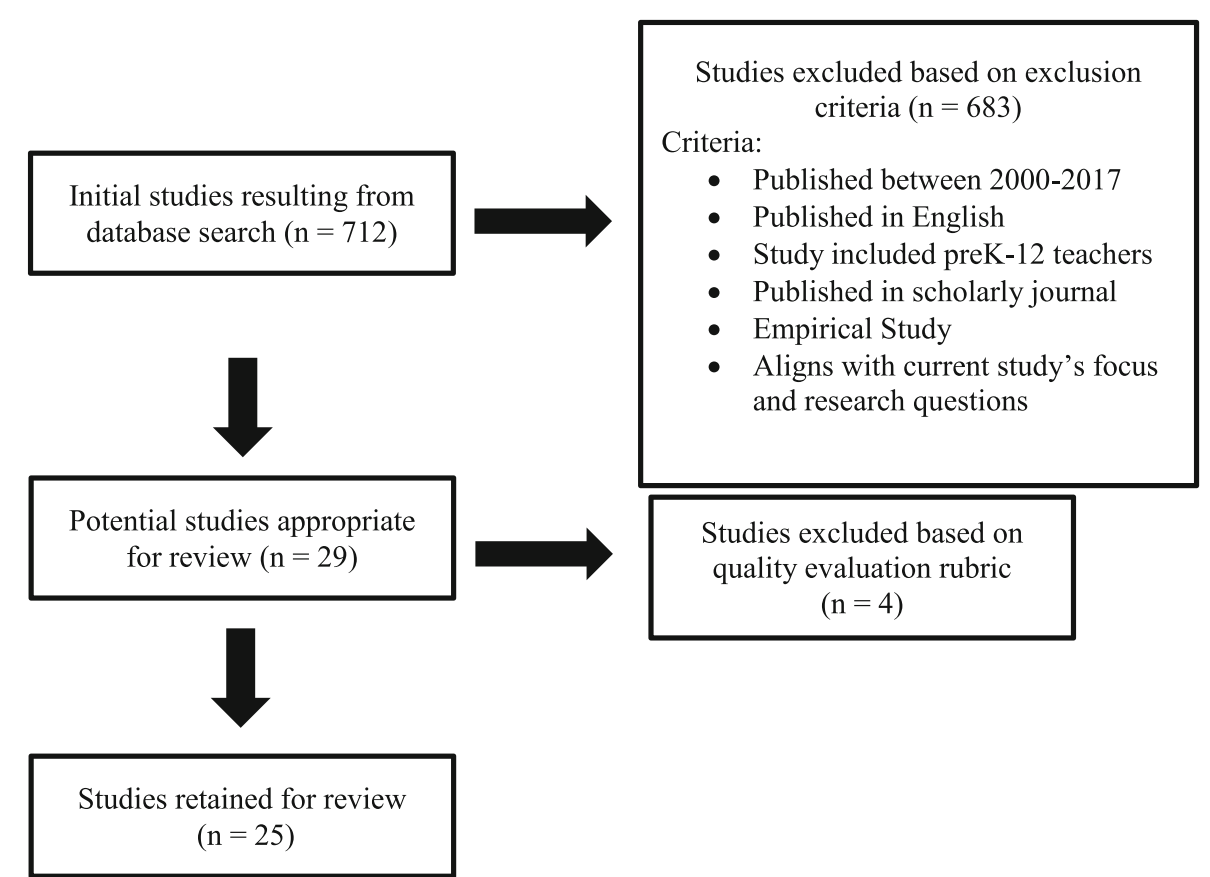

Fig. 1 Diagram of the screening process. The diagram shows how the studies were culled down from the initial database search to the final retained studies

into one of the four categories. Interrater reliability on those three articles was calculated using a percent agreement metric (McHugh 2012) with both raters assigning the text segment to the same category 42 out of 45 times for an agreement rate of .93 . The first author used this four-category protocol to code each of the remaining 22 articles. Five articles were selected at random for the second author to independently code to corroborate interrater reliability. Thus, a total of eight articles were coded by two raters-the first three and then five selected randomly. This yielded 129 extracted text segments assigned to the four broad categories. Both raters agreed on 116 of the 129 for an agreement rate of .90 . Analysis of those 13 disagreement codes helped both raters better understand the categories until both raters agreed on the assignment of each text segment. Both raters worked together to refine the broad codes into sub-codes (see Table 3 ) that could contextually be interpreted toward thematic findings. Approximately 430 total pieces of data as text segments, or codes, were extracted from the 25 articles.

\section{Results}

When examining the years each of the 25 retained articles was published, an interesting phenomenon was noted. The earliest date was 2010 , and then, the number of articles published on the topic each year increased, ending with five articles in 2017. This issue is of import beyond the USA as 20 of the articles retained were conducted in the USA, two in the UK, one in Saudi Arabia, one in Thailand, and one in South Korea. With regard to the methodology used in the retained studies, 12 of them were qualitative, seven used mixed methods, and six used a quantitative method to analyze the collected data. A summary of retained articles can be found in Table 4.

\section{How does existing research characterize teachers' perceptions of utilizing STEM pedagogy?}

Existing research gives us some insight into the beliefs teachers hold about STEM education. Several themes emerged to summarize existing research related to the following codes: teacher variables, application activities, cross-curricular integration, student enjoyment, student struggles, and value of STEM.

\section{Teacher variables}

Teachers' years of experience are inconsistently related to their perceptions of STEM integration or education, and teachers' value or interest in STEM may mediate the relationship (finding 1). For example, teacher's years of experience seem to have some influence on his/her feelings. One study showed more experienced teachers ( $>15$ years) had a more positive view of the importance of STEM education when compared with new teachers (between 1 and 5 years of experience) (Park et al. 2016), while two other studies showed teacher's years of experience were not associated with their knowledge of or 
Table 2 Quality assessment rubric

\begin{tabular}{|c|c|c|c|c|c|}
\hline & Criterion & 4—exceeds standard & 3-meets standard & 2-nearly meets standard & $\begin{array}{l}\text { 1-does not meet } \\
\text { standard }\end{array}$ \\
\hline I & $\begin{array}{l}\text { Objectives } \\
\text { and } \\
\text { purposes }\end{array}$ & $\begin{array}{l}\text { Clearly articulated problem, } \\
\text { objective, rationale, research } \\
\text { questions. }\end{array}$ & Adequately articulated. & Poorly articulated. & Incomplete. \\
\hline$\|$ & $\begin{array}{l}\text { Review of } \\
\text { literature }\end{array}$ & $\begin{array}{l}\text { Critically examines state of the } \\
\text { field. Clearly situates the topic } \\
\text { within the broader field. Makes } \\
\text { compelling connections to past } \\
\text { work. Discusses and resolves } \\
\text { ambiguities in definitions. } \\
\text { Synthesizes and evaluates ideas; } \\
\text { offers new perspectives. }\end{array}$ & $\begin{array}{l}\text { Discusses what has and has not } \\
\text { been done. Situates topic within } \\
\text { the broader field. Makes } \\
\text { connections to past work. } \\
\text { Defines key vocabulary. } \\
\text { Synthesizes and evaluates ideas. }\end{array}$ & $\begin{array}{l}\text { Minimally discusses what has } \\
\text { and has not been done. Vaguely } \\
\text { discusses broader field. Makes } \\
\text { few connections to past work. } \\
\text { Lacks synthesis across literature. } \\
\text { Minimal evaluation of ideas. }\end{array}$ & $\begin{array}{l}\text { Fails to discuss what has } \\
\text { and has not been done. } \\
\text { Topic not situated within } \\
\text { broader literature. No } \\
\text { connections to past work. }\end{array}$ \\
\hline III & $\begin{array}{l}\text { Theoretical } \\
\text { or } \\
\text { conceptual } \\
\text { frameworks }\end{array}$ & $\begin{array}{l}\text { Clearly articulated and described } \\
\text { in detail. Frameworks align with } \\
\text { study purposes. }\end{array}$ & $\begin{array}{l}\text { Articulated; aligns with study } \\
\text { purposes. }\end{array}$ & $\begin{array}{l}\text { Implied or described in vague } \\
\text { terms, or fails to align with } \\
\text { purposes. }\end{array}$ & Absent. \\
\hline IV & Participants & $\begin{array}{l}\text { Detailed, contextual description } \\
\text { of population, sample and } \\
\text { sampling procedures. }\end{array}$ & $\begin{array}{l}\text { Detailed description of } \\
\text { population, sample and } \\
\text { procedures. }\end{array}$ & $\begin{array}{l}\text { Basic description of sample and } \\
\text { procedures. }\end{array}$ & Incomplete. \\
\hline V & Methods & $\begin{array}{l}\text { Instruments and their } \\
\text { administration described in } \\
\text { detail. Evidence for validity and } \\
\text { reliability. Documented best } \\
\text { research practices. Potential bias } \\
\text { considered. }\end{array}$ & $\begin{array}{l}\text { Instruments and their } \\
\text { administration described. } \\
\text { Evidence for validity or reliability. } \\
\text { Some evidence of best research } \\
\text { practices. Potential bias } \\
\text { considered. }\end{array}$ & $\begin{array}{l}\text { Instruments described. } \\
\text { Incomplete evidence of validity } \\
\text { or reliability. Questionable } \\
\text { research practices. }\end{array}$ & Incomplete. \\
\hline $\mathrm{Vl}$ & $\begin{array}{l}\text { Results and } \\
\text { conclusions }\end{array}$ & $\begin{array}{l}\text { Detailed results. Exceptional use } \\
\text { of data displays. Discussion } \\
\text { clearly connects findings to past } \\
\text { work. Proposes future directions } \\
\text { for research. Conclusions clearly } \\
\text { address the problem or } \\
\text { questions. }\end{array}$ & $\begin{array}{l}\text { Complete results. Sufficient use } \\
\text { of data displays. Discussion } \\
\text { connects findings to past work. } \\
\text { Conclusions address the } \\
\text { problems or questions. }\end{array}$ & $\begin{array}{l}\text { Basic results. Insufficient use of } \\
\text { data displays. Discussion fails to } \\
\text { connect findings to past work. } \\
\text { Conclusions summarize findings. }\end{array}$ & Incomplete. \\
\hline VII & Significance & $\begin{array}{l}\text { Clearly and convincingly } \\
\text { articulates scholarly and } \\
\text { practical significance of the } \\
\text { study. }\end{array}$ & $\begin{array}{l}\text { Articulates scholarly and practical } \\
\text { significance of the study. }\end{array}$ & $\begin{array}{l}\text { Articulates scholarly or practical } \\
\text { significance, but is neither clear } \\
\text { nor convincing. }\end{array}$ & Not articulated. \\
\hline
\end{tabular}

comfort with teaching STEM (Nadelson et al. 2013; Srikoom et al. 2017). Another study found teachers with moderate experience (between 6 and 15 years) were actually least familiar with engineering characteristics and likely to have a bias against female students' ability to learn STEM (Hsu et al. 2011). While Park et al. (2017) found that, for participants who valued STEM education, as teaching experience increased, so too did a

Table 3 Four pre-established codes with refined sub-codes

\begin{tabular}{ll}
\hline Teachers & Students \\
- Professional development & - Student struggles \\
- Prior experiences with STEM & - Enjoyment of STEM activities \\
- Working in collaborative teams & - Student concerns \\
- Time (not enough) & \\
- Knowledge of STEM disciplines & \\
- Teachers' value of STEM education & \\
District & Curriculum \\
- Support systems & - Cross-curricular integration \\
- Assessments & - Application activities \\
- Structural issues & - Curriculum materials \\
& - STEM pedagogy \\
\hline
\end{tabular}

teachers' readiness level for teaching STEM. However, teachers who did not value STEM education did not show higher readiness levels with more years of experience. These teachers' years of experience made no difference in their feelings of preparedness with teaching STEM. Stohlmann et al. (2012) also found teacher passion toward STEM education affected their confidence and comfort in implementing the curriculum. Perhaps valuing this type of pedagogy mediates growth in teacher readiness, and this variable should be considered more frequently.

Age, gender, and STEM experiences of teachers may also play a role in their perceptions of STEM education (finding 2). Nadelson et al. (2013) found as teachers' age increased so did their positive attitude toward engineering in the classroom. Female teachers have been shown to perceive technology as less important within the STEM field than their male colleagues (Smith et al. 2015) and have also been found to have a more negative view in general of STEM education than male teachers (Park et al. 2016). 
Table 4 Summary of included empirical articles

\begin{tabular}{|c|c|c|c|}
\hline $\begin{array}{l}\text { Author(s) } \\
\text { (year) }\end{array}$ & Participants & Methodology & Findings \\
\hline $\begin{array}{l}\text { Al Salami et } \\
\text { al. (2017) }\end{array}$ & $\begin{array}{l}42 \text { middle and high school } \\
\text { teachers in USA }\end{array}$ & $\begin{array}{l}\text { Pretest-posttest surveys administered with PD and } \\
\text { teaching a STEM unit. } 29 \text { of the teachers also } \\
\text { answered } 2 \text { open-ended questions about successes } \\
\text { and challenges with implementation of STEM. }\end{array}$ & $\begin{array}{l}\text { No overall significant change from pretest to } \\
\text { posttest in attitudes toward STEM. Qualitative } \\
\text { findings of the challenges and barriers teachers felt } \\
\text { are as follows: (1) students' background knowledge } \\
\text { and skills, (2) students' buy-in, (3) securing supplies/ } \\
\text { expenses, (4) students' group, (5) using fellows, (6) } \\
\text { time constraints, (7) meeting mandated require- } \\
\text { ments, and (8) cross-content collaboration }\end{array}$ \\
\hline
\end{tabular}

Asghar et 25 teachers at a STEM

al. (2012) workshop in the USA

Bagiati and 1 preschool teacher at a Evangelou university-based lab school (2015) in the USA

Bell (2016) 19 secondary design and technology teachers in England and Wales

Bruce-Davis Students, teachers, and et al. (2014) administrators at 6 STEM high schools in the USA

Clark and Andrews (2010) 30 teachers, govt. reps, and engineering non-profit in the UK

Dare et al. $\quad 48$ 9th grade physical (2014) science teachers in the USA were analyzed to identify recurring patterns through an inductive and deductive coding process.

were analyzed using the const method.

During a 2-week long engineering related lesson, field notes, journal entries, and interview notes were analyzed using open coding and a phenomenological framework.

Phenomenography was used to analyze interview transcript data. Interrelated themes were identified and data categories of description were formed.

Grounded theory methodology using findings of an exploratory study that identified and analyzed perceptions of elementary level engineering education.

Mixed methods methodology using observations, interviews and surveys

El-Deghaidy 21 male middle school et al. (2017) science teachers in Saudi Arabia

Qualitative methodology included focus group discussions and an interview protocol.

Goodpaster 6 rural STEM teachers in the et al. (2012) USA

Herro and Quigley (2017)

21 middle school math and science teachers in the USA

Descriptive case study of teachers participating in a year-long STEAM PD using observations, written reflections, focus group interviews, and teachercreated artifacts.

Observations and interviews examining teachers' conceptions related to their implementation of STEM materials were coded using Productive Pedagogies framework.
Major themes found (1) initial perceptions, (2) perceptions after PD, (3) integrating STEM content and pedagogy, (4) problems with model problems, and (5) barriers to implementation.

Facilitators and barriers of implementation from both the teacher's and researcher's perspective were found. Regarding facilitators, teacher motivation is at top of influential factors. Barriers included teacher apprehension of engineering content and practical constraints (time, scheduling, and attendance).

Four empirically grounded outcome spaces found (1) externally imposed knowledge, (2) internal engagement with knowledge, (3) understanding learned, and (4) STEM understanding taught. Findings indicate when a teacher's knowledge is limited, student learning is limited.

Three themes emerged (1) a common vision of a challenging and engaging learning environment, (2) a focus on applying curricular and instructional strategies and practices to real-world problems, and (3) an appreciation for academic and affective support in the challenging learning environment.

Three main findings are (1) pedagogic issues, (2) exposure to engineering within the curriculum, and (3) children's interest

Teachers focused on soft skill integration (teamwork and communication) instead of engineering content. Teachers felt student engagement and enjoyment were important considerations for STEM.

The five patterns that emerged from focus groups were (1) STEM as interdisciplinary, (2) STEM as linked to life, (3) twenty-first century skills and careers, (4) pedagogical content knowledge and STEM, (5) STEM school culture, (6) factors facilitating STEM implementation, and (7) factors hindering STEM implementation.

Community interactions, professional development, and rural school structures emerged as three key factors. Participants felt each of these factors had both positive and negative implications.

Teachers increased their understanding of STEAM to teach content and perceived the PD as effective in changing their practices. They felt collaboration and integrated technology were important considerations to effect successful STEAM implementation.

Common conceptions that influenced teacher implementation were (1) negative beliefs about student abilities, (2) lack of subject matter knowledge, and (3) non-traditional beliefs about teaching that led to use of pedagogical techniques 
Table 4 Summary of included empirical articles (Continued)

\begin{tabular}{|c|c|c|c|}
\hline $\begin{array}{l}\text { Author(s) } \\
\text { (year) }\end{array}$ & Participants & Methodology & Findings \\
\hline & & & similar to those of the curriculum creators. \\
\hline $\begin{array}{l}\text { Hsu et al. } \\
\text { (2011) }\end{array}$ & $\begin{array}{l}192 \text { elementary teachers in } \\
\text { the USA }\end{array}$ & $\begin{array}{l}\text { DET survey results were examined using non- } \\
\text { parametric tests (Mann-Whitney and Kruskal-Wallis). }\end{array}$ & $\begin{array}{l}\text { Participants felt design, engineering, and } \\
\text { technology (DET) is important, but felt unfamiliar } \\
\text { with the content. Teacher motivations to teach DET } \\
\text { differed based on their ethnic backgrounds. }\end{array}$ \\
\hline $\begin{array}{l}\text { Lehman et } \\
\text { al. (2014) }\end{array}$ & $\begin{array}{l}40 \text { 6th grade teachers and } \\
10 \text { university faculty in the } \\
\text { USA }\end{array}$ & $\begin{array}{l}\text { Mixed methods using surveys and interviews. } \\
\text { Interpretive phenomenological analysis was used } \\
\text { for qualitative data and ANOVA for quantitative } \\
\text { data. }\end{array}$ & $\begin{array}{l}\text { Quantitative results suggest teachers and faculty } \\
\text { demonstrate elements of collaboration similar to } \\
\text { those of an effective community of practice, and } \\
\text { qualitative data identified factors that participants } \\
\text { felt were important (dialog, decision-making, action } \\
\text { taking, and evaluation.) }\end{array}$ \\
\hline $\begin{array}{l}\text { Lesseig et } \\
\text { al. (2016) }\end{array}$ & $\begin{array}{l}34 \text { grade } 6-8 \text { teachers in } \\
\text { the USA }\end{array}$ & $\begin{array}{l}\text { Case study of observations, field notes, artifacts, } \\
\text { and video during implementation of STEM design } \\
\text { challenges. }\end{array}$ & $\begin{array}{l}\text { Teachers valued STEM practices and learner } \\
\text { motivation/engagement. Challenges associated } \\
\text { with pedagogy, curriculum, and school structures } \\
\text { were identified. }\end{array}$ \\
\hline $\begin{array}{l}\text { McMullin } \\
\text { and Reeve } \\
\text { (2014) }\end{array}$ & $\begin{array}{l}\text { Phase } \|-33 \text { teachers, } 29 \\
\text { counselors, and } 29 \\
\text { administrators in the USA }\end{array}$ & $\begin{array}{l}\text { Phase I led to factors that contribute to program } \\
\text { success; Phase II—-surveys over these factors with } \\
\text { comment boxes were sent to participants and } \\
\text { descriptive statistics for each group were analyzed. }\end{array}$ & $\begin{array}{l}\text { Factors found necessary for successful program } \\
\text { were supportive administrators, supportive } \\
\text { counselors, and dynamic teachers. Teachers felt } \\
\text { high-quality curriculum and meeting program goals } \\
\text { were important. They felt providing career path- } \\
\text { ways for students and opportunities for engineer- } \\
\text { ing related education were goals for } \\
\text { implementation. }\end{array}$ \\
\hline
\end{tabular}

Nadelson et 33 elementary teachers in Demographics, confidence for teaching STEM al. (2013) the USA survey, and a survey of efficacy for teaching STEM were analyzed for correlations pre and post PD.

\author{
Nadelson $377 \mathrm{~K}-12$ teachers in the \\ and Seifert USA
}

(2013)

Nadelson et 230 grade $4-9$ teachers in al. (2012) the USA.

Park et al. 705 STEAM teachers in (2016) South Korea

Park et al. $\quad 830$ early childhood (2017) teachers in preschool third grade in the USA

Smith et al. 280 secondary agriculture (2015) teachers in the USA
Several STEM teaching surveys were administered pre and post STEM institute then descriptive statistics and correlations were found.

Pre- and post- survey results of various STEM implementation factors were analyzed using descriptive statistics and correlations.

Online surveys of beliefs and perceptions toward STEAM and demographic data were analyzed using OLS regression.

Online survey of teachers' beliefs about readiness for teaching STEM was examined using latent class analysis. Open-ended survey questions were used to reveal themes about their opinions about STEM education.

Descriptive survey methods were used. Online survey results were analyzed using MANOVA and descriptive statistics were found.

Using survey data, descriptive statistics, and ANOVA were used for quantitative analysis. Interpretive methods were used for qualitative analysis.
Significant and consistent increases in pre- to postPD of teacher confidence, efficacy, and perceptions of STEM. Also, increased links between STEM curriculum and instruction to learning standards were made by teachers.

Participants had an average level of comfort teaching STEM before the institute, which increased significantly after the institute. Some teacher characteristics, perceptions, and practices were related to one another.

Participants' perceptions and conceptions of STEM achieved substantial gains after the STEM institute. Perceptions of efficacy for teaching STEM was found related to comfort with teaching STEM, pedagogical discontentment with teaching STEM and inquiry implementation.

Although the majority of teachers had a positive view of STEAM education, they noted challenges to successful implementation such as time, increases in workload, and lack of financial and administrative support.

Teachers' teaching experience and their awareness of the importance of STEM played a differential role in the classification of teachers into latent classes. Themes from open-ended questions revealed teachers felt these were challenges: (1) lack of time to teach STEM, (2) lack of administrative support, (3) lack of PD, (4) lack of knowledge about STEM topics, (5) lack of parental participation, and (6) reluctance of teachers to collaborate.

Teachers felt each of the four components of STEM integration important. They had high levels of confidence in integrating science and math, but lower confidence levels for teaching technology and engineering.

Majority of teachers (85.5\%) had not heard of STEM education and $19 \%$ could not provide a definition of it. Teachers felt STEM education is important, but 
Table 4 Summary of included empirical articles (Continued)

\begin{tabular}{|c|c|c|c|}
\hline $\begin{array}{l}\text { Author(s) } \\
\text { (year) }\end{array}$ & Participants & Methodology & Findings \\
\hline & & & have concerns about the engineering discipline. \\
\hline $\begin{array}{l}\text { Stohlmann } \\
\text { et al. (2012) }\end{array}$ & $\begin{array}{l}4 \text { middle school STEM } \\
\text { teachers in the USA }\end{array}$ & $\begin{array}{l}\text { Field notes, observations, and interviews, collected } \\
\text { over school year, were analyzed using constant } \\
\text { comparative method. }\end{array}$ & $\begin{array}{l}\text { Content and pedagogical knowledge were found } \\
\text { to contribute to positive self-efficacy. Teacher felt } \\
\text { these supports are needed for successful STEM edu- } \\
\text { cation: (1) partner with university or nearby school, } \\
\text { (2) attend PD, (3) teacher collaboration time, and } \\
\text { (4) curriculum company training and contacts. }\end{array}$ \\
\hline $\begin{array}{l}\text { Van } \\
\text { Haneghan } \\
\text { et al. (2015) }\end{array}$ & $\begin{array}{l}43 \text { middle school math, } \\
\text { science, and technology } \\
\text { teachers in the USA }\end{array}$ & $\begin{array}{l}\text { Surveys of teacher efficacy in teaching STEM were } \\
\text { analyzed using } t \text { tests Pearson correlations, Fisher's } \\
\text { exact test, and for descriptive comments. }\end{array}$ & $\begin{array}{l}\text { Teachers believe they have the instructional skills, } \\
\text { professional development, and resources to carry } \\
\text { out engineering design challenges, but some did } \\
\text { not feel confident in their ability to foster intrinsic } \\
\text { motivation in students. }\end{array}$ \\
\hline $\begin{array}{l}\text { Wang et al. } \\
(2011)\end{array}$ & $\begin{array}{l}3 \text { middle school teachers } \\
\text { that participated in a year- } \\
\text { long PD on STEM in the } \\
\text { USA }\end{array}$ & $\begin{array}{l}\text { Qualitative case study was used to determine } \\
\text { teachers' beliefs about and perceptions of STEM } \\
\text { integration. Constant comparative method was } \\
\text { used to analyze data. }\end{array}$ & $\begin{array}{l}\text { Technology was the hardest discipline to integrate. } \\
\text { The problem-solving process is a key component } \\
\text { to successfully integrating STEM disciplines. } \\
\text { Teachers in different STEM disciplines have different } \\
\text { perceptions about STEM that leads to different } \\
\text { classroom practices. Teachers are aware they need } \\
\text { to add more content knowledge in their STEM } \\
\text { integration. }\end{array}$ \\
\hline
\end{tabular}

A relationship $(r=.21, p<.05)$ was found between the number of college level math or science courses taken and a teacher's comfort level for teaching STEM, such that the more courses taken the more comfortable the teacher (Nadelson et al. 2012). Differences also seem to exist between elementary and secondary teachers. Secondary teachers have been found to have a more negative view of the potential impact of STEM education on student achievement when compared to elementary teachers (Park et al. 2016). Srikoom et al. (2017) found the strongest concerns in teachers of grades 1-3 and 7-9. This is consistent with the findings of Park et al. (2017), where only one-third of the early childhood teachers surveyed felt prepared to teach STEM. Middle school teachers (6th-8th grades) reported concern with lesson planning without knowledge of the duration students would need for each task. These teachers were also concerned with their ability to guide students in this type of interdisciplinary learning (Stohlmann et al. 2012). In addition, a group of middle school teachers identify the importance of professional development and experience in working with engineering in the curriculum. Teachers with prior experiences with engineering scored higher on their knowledge of instructional techniques associated with STEM education and their ability to meet the goals of STEM education (Van Haneghan et al. 2015). For all teachers, knowledge of STEM content seems to matter. Teacher efficacy, confidence, and comfort for teaching STEM all appear to be positively correlated to knowledge of STEM content (Nadelson et al. 2012; Nadelson et al. 2013).

\section{Application activities}

Teachers emphasize the importance of student participation in application activities within STEM education as a crucial indicator of their academic achievement (finding 3). The hands-on, application activities that are a fundamental part of STEM education are highly valued by teachers as a necessary and beneficial tool for student learning outcomes. Teachers also note that these engaging, kinesthetic activities motivate their students (Bruce-Davis et al. 2014; Dare et al. 2014; Goodpaster et al. 2012; Van Haneghan et al. 2015). Early childhood teachers believed these types of learning experiences were not only developmentally appropriate, but would also build a strong foundation of each of the STEM subject areas (Park et al. 2017). Secondary teachers felt the engineering-based hands-on activities would be particularly useful as students are mastering math concepts (Asghar et al. 2012). Rural teachers also noted the value of these activities as they allow students to link science to their rural lives (Goodpaster et al. 2012).

\section{Cross-curricular integration}

Teachers perceive that the cross-curricular nature of STEM education is beneficial to student learning, but secondary teachers may perceive barriers or challenges to cross-curricular programs (finding 4). They believe including engineering with the other subjects adds valuable problem-solving and real-world aspects to instruction that will give students an advantage in preparation for their futures. The cross-curricular connections students make are seen as an advantage to STEM education as they give students necessary skills to approach and solve problems similar to those they will encounter in future careers (Asghar et al. 2012; Bruce-Davis et al. 2014; Dare et al. 2014; McMullin and Reeve 2014; Smith et al. 2015). Technology teachers 
were particularly interested in using this integrated cross-curricular approach in their classrooms (Asghar et al. 2012).

Although secondary teachers (grades 6-12) considered collaboration across disciplines an important success, they also reported concerns about limited communication between subject area teachers (Al Salami et al. 2017). In another study, middle school teachers expressed concerns about scheduling and content standards they felt might inhibit cross-curricular teaching (Herro and Quigley 2017). The same teachers felt collaboration and technology would be important to transdisciplinary teaching. The concept of interdisciplinarity was difficult for some secondary teachers to grasp, with a perception that integration between two subjects was possible but putting the four STEM disciplines together was problematic (El-Deghaidy et al. 2017). El-Deghaidy et al. (2017) also found the teachers did not have a clear understanding of how to integrate technology, believing it was just hardware.

\section{Student enjoyment}

Teachers believe STEM education is inherently motivating to students (finding 5). Teachers feel the persistence and interest gained by students are very valuable as they work on STEM challenges and that students eventually begin to feel motivated and empowered by their ability to solve complex problems. The complex, open-ended design of STEM challenges also lead to student increases in academic achievement. Teachers commented that the addition of engineering to their math and science curricula brings them to life. They also felt students are genuinely interested in STEM problems. Teachers note an overwhelmingly positive response from students during STEM education. Moreover, teachers felt this increase in student enjoyment and engagement was the main reason for integrating STEM into their curriculum (Dare et al. 2014; Herro and Quigley 2017; Lesseig et al. 2016; McMullin and Reeve 2014; Srikoom et al. 2017; Van Haneghan et al. 2015).

\section{Student struggles}

Teachers believe that struggle and even failure are inherent yet valuable components of the engineering design process within STEM education (finding 6). Students are asked to improve upon their designs and solutions. They are encouraged to take risks. Teachers feel this is beneficial to students, especially high-achieving students that typically do not reach a point of frustration in their classrooms (Dare et al. 2014). Because failure is part of the process, it is expected and therefore accepted. This encourages students to do things they do not know how to do and challenge themselves to confront failure. Teachers feel this helps encourage students to think for themselves and better understand the content in their classes by thinking critically about it (Holstein and Keene 2013). Teachers value these authentic learning experiences, without one right answer (Bruce-Davis et al. 2014). They felt students needed lots of practice participating in group work and learning through doing in order to be successful with STEM learning (El-Deghaidy et al. 2017; Herro and Quigley 2017). Several teachers were happily surprised that low-performing students were able to be successful in the less-structured and more challenging STEM problems (Lesseig et al. 2016; Wang et al. 2011). Teachers even reported that students were reluctant to begin with the STEM equipment because they were afraid it would be damaged. Students had to learn that making mistakes was going to happen and experimenting with the equipment would help them solve their STEM problem (Dare et al. 2014).

\section{Value of STEM}

Teachers' efficacy beliefs and the value they place on STEM education seems to influence their willingness to engage and implement STEM curriculum (finding 7). Student learning is limited when teachers' knowledge and understanding is deficient (McMullin and Reeve 2014). Teachers who have limited knowledge and comfort with STEM may feel they are unable to contribute to classroom learning during STEM activities. On the other hand, teachers that feel they have the knowledge and skill sets to implement STEM activities have a high self-efficacy toward this type of learning. Teacher perceptions of the importance of STEM influence their ability to learn and develop as STEM educators (Bell 2016). This will affect how they teach STEM curriculum. Teachers have reported challenges associated with learning the content while teaching multiple courses together (El-Deghaidy et al. 2017; Goodpaster et al. 2012; Herro and Quigley 2017). Teachers felt developing new STEM problems while integrating different domains was difficult. Teachers also reported trouble combining the STEM pedagogical approach with their typical content concepts (Asghar et al. 2012). These teachers seemed to be unable to see these things as anything but separate. Even after professional development, some teachers are still uncomfortable using STEM activities in their classroom (Asghar et al. 2012; Herro and Quigley 2017). Many professional development facilitators have seen resistance by teachers to utilizing STEM (Dare et al. 2014; Holstein and Keene 2013). STEM teachers show a range of fidelity with implementation, and engineering appears to be the content area teachers are least confident in teaching (Smith et al. 2015; Srikoom et al. 2017). This may be why there is a lack of evidence that engineering decisions are explicitly being made by teachers and 
students during STEM education (Lehman et al. 2014; Van Haneghan et al. 2015).

While some teachers saw STEM as one more thing they needed to cover in their classrooms, many teachers felt it was a valuable way for students to learn. Teachers felt strongly that STEM should be integrated into students' K-12 education (Hsu et al. 2011; McMullin and Reeve 2014; Smith et al. 2015). In other words, they felt STEM is important. Teachers believed STEM leads to higher expectations for students after high school and felt increases in scientific literacy were valuable as they challenge students to think critically about current issues and future implications in their own lives (Bruce-Davis et al. 2014; El-Deghaidy et al. 2017; Herro and Quigley 2017). These K-12 elementary and secondary teachers $(n=729)$ believed STEM education has a positive impact on student learning and outcomes (Park et al. 2016). Teachers also experienced rewarding feelings of making a difference with students and their communities when utilizing STEM education (Hsu et al. 2011; Goodpaster et al. 2012; Wang et al. 2011). Teachers seemed to focus on how they could improve their STEM lessons the next time they use them. They were working on future improvements almost as soon as the lesson was over (Dare et al. 2014).

Teacher perceptions of STEM education influence how they design their STEM units and their methods of delivery of instruction. A dynamic teacher with a positive attitude toward STEM seems to be the single most important factor to implementation fidelity and STEM program success (McMullin and Reeve 2014). These teachers believe STEM integration can improve their students' learning outcomes (Bagiati and Evangelou 2015; Dare et al. 2014; El-Deghaidy et al. 2017; Wang et al. 2011).

\section{What do teachers identify as challenges and barriers to using STEM pedagogy in their classrooms?}

The area teachers identified as challenges and barriers related to STEM education can be organized in six categories: pedagogical challenges, curricular challenges, structural challenges, student concerns, assessment concerns, and teacher supports.

\section{Pedagogical challenges}

Teachers perceive that STEM pedagogy requires some fundamental shifts in how they establish classroom environments and teach, and for some teachers these shifts are not always positive (finding 8). Several pedagogical challenges were cited by teachers as inhibiting factors to STEM implementation. For example, teachers mention STEM pedagogy requires a fundamental shift away from teacher-led instruction to student led-instruction (Lesseig et al. 2016; Park et al. 2017). Teachers have to be able to step out of the director role and allow students to find their own way during the lesson, which might involve unexpected directions (Lesseig et al. 2016). Another similar concern is that teachers must have a view of instruction that aligns with the philosophy of the STEM curriculum authors. There must be a match between the teachers' pedagogy and the curriculum pedagogy (Holstein and Keene 2013). Teachers voiced a concern that they might incorrectly or inadvertently misinterpret the STEM developer's expectations (Bagiati and Evangelou 2015; Holstein and Keene 2013). Teachers also expressed concerns about STEM pedagogy meeting the diverse needs of all learners, particularly those with disabilities and various cognitive abilities (Herro and Quigley 2017; Park et al. 2017). One last pedagogy concern suggests that utilization of STEM could actually hinder direct instruction of science content. Dare et al. (2014) found secondary teachers noted that they were not teaching science concepts as well when utilizing STEM in their classrooms.

\section{Curriculum challenges}

Some teachers, especially at the high school level, perceive the integrated nature of STEM curriculum is a challenge (finding 9). Teachers had apprehension about following someone else's curriculum plan (Bagiati and Evangelou 2015). Teachers were also concerned about integrating STEM curriculum into their existing curricula. District alignment and grade level standards can be inflexible, which prevents a smooth integration of STEM. In addition, teachers noted they felt STEM curriculum could be inflexible and the difficulty with combining two inflexible curricular plans (Bagiati and Evangelou 2015; Lesseig et al. 2016). Secondary teachers felt their domain specific courses (biology II, geometry, etc.) did not integrate well with other STEM disciplines (Asghar et al. 2012). Also, secondary teachers felt miscommunications between various STEM teachers' perception of each other's domain led to feelings of anger and subsequently caused interdisciplinary curriculum to fail. For similar reasons, teachers had concerns about developing their own STEM-based curriculum with teachers from other subject areas (Asghar et al. 2012; Bell 2016; El-Deghaidy et al. 2017). Teachers were also concerned about STEM curriculum's ability to impart meaningful learning (Asghar et al. 2012). When implementing STEM curriculum, teachers were observed treating the inclusion of specific content as more of an afterthought (Dare et al. 2014).

\section{Structural challenges}

Teachers perceived typical school structures are barriers to the implementation of STEM education (finding 10). Teachers felt the confines of class scheduling prohibited the interdisciplinary nature of STEM lessons, and 
various teachers teaching their own specific subjects were not conducive to interdisciplinary work either. This same scheduling prevented teachers in different subjects from planning together (Asghar et al. 2012; Dare et al. 2014; Lesseig et al. 2016). The structure of student schedules, and lack of flexibility in them, was also cited as a barrier to STEM (El-Deghaidy et al. 2017; Lesseig et al. 2016). Lack of control over pacing of curriculum and the sequence of instruction were also discussed as troublesome when teachers sought to integrate multiple disciplines for authentic STEM lessons (Herro and Quigley 2017). At the district level, teachers felt administrative and financial supports could be a challenge to STEM implementation (Asghar et al. 2012; Clark and Andrews 2010; Hsu et al. 2011; Park et al. 2016; Park et al. 2017). Another concern was a lack of technology resources available to students. Without student computers and other technology tools available, it was difficult to integrate the technology piece into STEM lessons (Wang et al. 2011). The last structural concern was the way education is organized and evaluated at the state level (Asghar et al. 2012).

\section{Student concerns}

Teachers believe that students are unable or unwilling to be successful with STEM education or initiatives (finding 11). Several studies reported teachers underestimate student abilities to solve STEM problems (Al Salami et al. 2017; Asghar et al. 2012; Bagiati and Evangelou 2015; Goodpaster et al. 2012; Van Haneghan et al. 2015). Many of these teachers did not believe their students were competent enough in content areas to apply these skills to self-directed STEM problems. They felt these types of problems would be very difficult for their students and would cause their students to become unmotivated to learn. Teachers reported a need for instructional tools they could use to motivate students and get them interested in STEM subjects. In addition, rural teachers noted the challenges associated with modifying the curriculum in order to meet the needs of underperforming students (Goodpaster et al. 2012). Teacher beliefs about their students may be related to their implementation fidelity of STEM curriculum (Holstein and Keene 2013).

\section{Assessments, time, and knowledge}

Teachers perceive that lack of quality assessment tools, planning time, and knowledge of STEM disciplines are challenges and barriers to STEM initiatives (finding 12). In one study, more than $40 \%$ of the teachers felt there was a lack of assessments for STEM programs (Nadelson and Seifert 2013). These teachers and many others felt there were not enough standardized classroom assessments to use with STEM lessons. This makes assessing student learning in a STEM curriculum very difficult. Teachers felt there were not enough formative assessments to discover what concepts students understood from other disciplines (Asghar et al. 2012; Dare et al. 2014). Additionally, teachers were concerned about group grading. They felt unsure of how they would assess each member of the group individually to make sure they had mastery of the standards (Herro and Quigley 2017). Formative assessments help teachers know when reteaching or remediating is necessary or when students already know the material.

Teachers were concerned with the increased workload associated with STEM programming. They have to find more time to plan with other subject areas and to prepare the materials for students. Presenting the material and allowing for varying ability levels among students also required more time. This makes a lack of time one of the primary concerns teachers had when implementing STEM (Bagiati and Evangelou 2015; Hsu et al. 2011; Goodpaster et al. 2012; Park et al. 2016).

Teachers also believed they had a lack of subject matter knowledge concerning STEM content. Pre-service and in-service training was seen as inadequate in preparing teachers to implement STEM. Teachers felt they needed clarity about how the program was supposed to be implemented into existing programs (Nadelson and Seifert 2013). They did not feel fully prepared to integrate STEM subjects (Al Salami et al. 2017; Hsu et al. 2011). Teachers also perceived a lack of instructional resources was a hurdle in their path to provide STEM opportunities for students (Park et al. 2017). Although teachers deemed STEM education important and valuable, they were not comfortable with meeting the high teacher expectations they felt were associated with STEM. Feeling unsure about one's ability to teach STEM could lead teachers to a reduced confidence in their teaching efficacy (Bagiati and Evangelou 2015; Clark and Andrews 2010; Holstein and Keene 2013).

\section{What do teachers feel supports their efforts to implement STEM?}

Some studies captured ways that teachers might need an additional support. Five main areas were found in the research that addressed this need for support. They were in the areas of collaboration, curriculum, district support, prior experiences, and professional development.

\section{Collaboration}

Teachers believe that a culture of collaboration would increase the viability of STEM programs (finding 13; Asghar et al. 2012; Bruce-Davis et al. 2014; Herro and Quigley 2017; Lehman et al. 2014; Stohlmann et al. 2012; Wang et al. 2011). Teachers explained the importance of collaborating with other STEM teachers and 
university professionals in order to not only create an atmosphere that enhances preparation for STEM lessons, but also to model a team approach to students. STEM pedagogy required students to collaborate to solve challenges, so a teacher modeling the strength of a group approach is beneficial. One teacher noted that teachers had been siloed in the past, and an integrated team approach was necessary for STEM planning and implementation (Asghar et al. 2012). Other teachers attributed much of their success with STEM to partnerships with university faculty and accessing the expertise in their community (Lehman et al. 2014). Partnerships with museums and other community-based centers were helpful to capitalize on learning about STEM careers and experiences (El-Deghaidy et al. 2017). These supports helped the teachers feel comfortable taking risks and delving deeper into STEM concepts outside their comfort area.

Many teachers felt collaboration was the key to successful transdisciplinary teaching required for STEM lessons (Herro and Quigley 2017; Stohlmann et al. 2012). Teachers felt intentional time was necessary throughout the school year for various disciplines to meet together for planning in order to bridge the disciplines. They also believed a technology-enabled network could be an effective means of collaborating between content area teachers. Providing time and opportunities for collaborative planning and open communication between teachers may be critical to successful implementation.

\section{Curriculum}

Teachers believe that the availability of a quality curriculum would enhance the likelihood of success of STEM initiatives (finding 14; Asghar et al. 2012; Lehman et al. 2014; McMullin and Reeve 2014; Stohlmann et al. 2012; Van Haneghan et al. 2015; Wang et al. 2011). Teachers discussed the importance of a flexible curriculum that is engineering-based. In order to be effective, the curriculum must be flexible enough to be used with various ability levels and educational environments while still being focused on the engineering design process (Lehman et al. 2014). Teachers believed this type of curriculum increased their belief in themselves, or self-efficacy, to teach STEM (Lehman et al. 2014; Van Haneghan et al. 2015). The STEM curriculum or modules must also be explicitly and tightly connected to the standards. In addition, these modules need to be developmentally appropriate (Asghar et al. 2012). Teachers expressed a desire for specific, ready-made STEM problems they could use in their classrooms immediately. These problems must be grounded in the STEM disciplines and driven by the standards (Asghar et al. 2012; Wang et al. 2011). Also, there must be fidelity in the implementation of the curriculum such that the teachers utilize the expectations and goals intended by the curriculum designers (McMullin and Reeve 2014; Stohlmann et al. 2012).

\section{District support}

Teachers perceive school district support, guidance, and flexibility were necessary for STEM initiatives (finding 15). In fact, school district support was cited as the number one most important factor to STEM success in two of the studies (Bruce-Davis et al. 2014; McMullin and Reeve 2014). It was also mentioned by other studies as an important factor (Holstein and Keene 2013; Park et al. 2016). A supportive administrator or administrative team is important when teachers are implementing STEM pedagogy. Teachers believed guidance by and constant dialog with administrators is needed in order to successfully utilize STEM programs (El-Deghaidy et al. 2017; Holstein and Keene 2013; McMullin and Reeve 2014). Teachers believed it was necessary for their school districts to allow flexibility for them to expand the curricula and instruction beyond national and state standards, so they were able to offer problems that meet student interests, talents, and academic needs (Bruce-Davis et al. 2014). In addition, the K-12 curricular framework or scope and sequence should be restructured to allow for STEM programing (Herro and Quigley 2017; Park et al. 2016).

Teachers also felt that districts need to help parents and students understand course offerings and what STEM courses will teach them. Secondary teachers believed another important consideration is how high school credit will be given in these courses. More math or science credit might have increased student enrollment rather than only giving elective credits for taking STEM courses (McMullin and Reeve 2014).

\section{Prior experiences}

Teachers perceive that previous experience using student-centered, inquiry models of instruction facilitate success in a STEM initiative (finding 16). Similarly structured prior experiences by teachers were commonly seen as facilitators to STEM success. Teachers who had more science or math courses in college (Park et al. 2016) or had utilized similar instructional methods (i.e., problem-based learning, inquiry-based learning, questioning techniques, guided independent research studies) felt these experiences allowed them to promote the inductive and deductive reasoning across disciplines necessary for STEM (Bagiati and Evangelou 2015; Bruce-Davis et al. 2014; Park et al. 2017). Confidence with STEM pedagogy increased because of these prior experiences. 


\section{Professional development}

Teachers believe that well-organized and frequently available professional learning opportunities would facilitate successful STEM initiatives (finding 17). The most often mentioned support that would increase the effectiveness of STEM education was learning opportunities for teachers to increase their ability to effectively integrate STEM content into their curriculum. Teachers at multiple stages in their careers reported significant increases in their confidence, knowledge, and efficacy to teach STEM after attending professional development programs (Lesseig et al. 2016; Nadelson et al. 2012; Nadelson et al. 2013; Nadelson and Seifert 2013; Van Haneghan et al. 2015). Effective professional development or continuing education needs to provide time and structure for teachers to explore how STEM can be integrated within their curriculum while focusing on increasing teacher's content knowledge and experiences with STEM. Research indicates these factors will directly influence teacher practice and student learning (Nadelson et al. 2013; Van Haneghan et al. 2015). Teachers wanted more strategies to improve student performance in engineering design challenges (Bruce-Davis et al. 2014; Lesseig et al. 2016; Van Haneghan et al. 2015). Teachers need support when incorporating engineering into their math and science instruction (El-Deghaidy et al. 2017; Lehman et al. 2014). Teachers felt support for planning and implementation should be ongoing and include pedagogical tools they can use to increase student academic success (Lesseig et al. 2016).

The thematic analysis process began with assigning codes to segments of text followed by the grouping of those coded text segments. These grouped segments led to 17 findings that were supported by multiple text segments extracted from the qualified studies. Ultimately, these 17 findings suggest the following themes from this systematic review of research involving teachers' perceptions of STEM education initiatives:

- Variation among teachers' age, gender, experience, and perceived value of STEM education may influence their support and enthusiasm for schoolwide STEM initiatives.

- Secondary, especially high school, teachers seem more likely to perceive interdisciplinary STEM initiatives as challenges to what they believe to be high-quality learning opportunities for students.

- STEM education initiatives may require substantial shifts in pedagogy, curriculum, assessment, support, and training, and teachers are likely to see any of these as challenges and/or barriers.

- Teachers perceive the engaging and authentic nature of interdisciplinary STEM education initiatives as potentially beneficial for students.

\section{Discussion}

\section{Recommendations for practice}

In order to support teachers and STEM programs as they seek to develop STEM talent, necessary provisions must be provided so they can act as a facilitating catalyst in the student's development. It seems very promising that the results from multiple studies were so similar in their findings concerning challenges and supports. Teachers need quality curriculum that aligns with district and state guidelines and includes formative assessment techniques teachers can use to assess their students' conceptual understandings. Professional development that is attended by the team of teachers that will be utilizing the curriculum (Nadelson et al. 2012) and allows teachers to gain experience with STEM concepts and the pedagogy in a meaningful way is also necessary. The pedagogical strategies associated with STEM must be explicitly taught to teachers and modeled in order to improve fidelity of programming. Teachers have to become comfortable allowing their students to "take the wheel" and drive instruction. They have to learn how to play the role of facilitator of knowledge and how to encourage students to take academic risks. All of this can be practiced and reinforced in professional development before implementation in classrooms. The National Research Council (2013) recommends that districts develop a mechanism for focused professional development to be coordinated that aligns with instructional reforms and provides high-quality learning opportunities for teachers. The content knowledge and affective needs teachers have regarding STEM instruction must be attended to during in-service learning.

District administrators must be aware of the need for increased time to collaborate with the other STEM teachers. Building time into the school year for teachers to plan lessons and prepare lessons with colleagues would facilitate STEM integration. As teachers move from teaching single subjects to teaching cross-curricular units, they will need time to work together. Teachers need to be encouraged to work together to create innovative ways to successfully integrate this multidisciplinary way of thinking and learning. An open and transparent means of communicating is necessary within the school and district concerning teacher needs and supports regarding STEM education.

\section{Recommendations for future research}

More studies that document the success of STEM programs with low ability and diverse student populations would be beneficial encouragement to teachers. Teachers need to believe all students can benefit from STEM instruction. As they begin to experience student success in their classrooms, they will be encouraged to continue implementing STEM activities. 
A study examining differences in STEM perception among gifted and non-gifted educators would be interesting in light of the pedagogical similarities between STEM and gifted education (Mann and Mann 2017). An examination of the confidence levels of these two groups of teachers as they develop STEM talent within their classrooms would yield useful data for future professional development.

Further study of effective implementation of the core tenets Moore et al. (2014) suggested should be conducted in classrooms in various school settings (urban, rural, and suburban). There may be specific pedagogical needs within different settings that can be addressed with teacher in-service instruction.

Research into effective formative assessment strategies during STEM education needs to be conducted. Teachers felt this was a missing component of STEM programs (Asghar et al. 2012; Dare et al. 2014). Effective ways to gauge student understanding would yield more efficient STEM talent development. Teachers could better differentiate for various ability levels within their classrooms if they better understand each student's progress throughout the unit (Tomlinson and Moon 2013).

More work needs to be done in order to understand how best to support teachers as they attempt to integrate STEM education into their classrooms (Dare et al. 2014).

\section{Conclusions}

The 17 findings from this study should be used to guide school/district STEM initiatives. Because these 17 findings were found across multiple studies, they could help inform future professional development and teacher initiatives to improve teacher efficacy related to STEM instruction/integration.

Teachers appear to value STEM education and believe it enhances student-learning outcomes while preparing students for their future. With increased confidence, teachers would likely be more effective at integrating STEM activities. The research seems clear that increased confidence leads to better performance during instruction, and this will lead to gains in student learning (Nadelson et al. 2012; Nadelson et al. 2013).

\section{Acknowledgements}

Not applicable

\section{Funding}

There are no sources of funding for this study.

\section{Availability of data and materials}

All data were found on the following databases: Academic Search Complete, ERIC via Ebscohost, PsychINFO via Ebscohost, and Google Scholar.

\section{Authors' contributions}

Both authors read and approved the final manuscript.

\section{Competing interests}

The authors declare that they have no competing interests.

\section{Publisher's Note}

Springer Nature remains neutral with regard to jurisdictional claims in published maps and institutional affiliations.

\section{Author details}

${ }^{1}$ Department of Teaching and Learning, Grand Valley State University, 401 Fulton St. W, Grand Rapids, MI 49504, USA. ${ }^{2}$ School of Education, Baylor University, Waco, USA.

Received: 30 May 2018 Accepted: 10 December 2018

Published online: 14 January 2019

\section{References}

Articles included in the review are indicated by an asterisk (*).

Al Salami, M. K., Makela, C. J., \& de Miranda M. A. (2017). Assessing changes in teachers' attitudes toward interdisciplinary STEM teaching. International Journal of Technology and Design Education, 27, 63-88. https://doi.org/10. 1007/s10798-015-9341-0.

Asghar, A., Ellington, R., Rice, E., Johnson, F., \& Prime, G. M. (2012). Supporting STEM education in secondary science contexts. The Interdisciplinary Journal of Problem-based Learning, 6(2), 85-125. https://doi.org/10.7771/1541-5015.1349.

Bagiati, A., \& Evangelou, D. (2015). Engineering curriculum in the preschool classroom: the teacher's experience. European Early Childhood Education Research Journal, 23(1), 112-128. https://doi.org/10.1080/1350293X.2014. 991099.

Bell, D. (2016). The reality of STEM education, design, and technology teachers' perceptions: a phenomenographic study. International Journal of Design Education, 26, 61-79. https://doi.org/10.1007/s10798-015-9300-9.

Braun, V., \& Clarke, V. (2006). Using thematic analysis in psychology. Qualitative Research in Psychology, 3, 77-101. https://doi.org/10.1191/ 1478088706qp063oa.

Bruce-Davis, M. N., Gubbins, E. J., Gilson, C. M., Villanueva, M., Foreman, J. L., \& Rubenstein, L. D. (2014). STEM high school administrators', teachers', and students' perceptions of curricular and instructional strategies and practices. Journal of Advanced Academics, 25(3), 272-306. https://doi.org/10.1177/ $1932202 \times 14527952$.

Chamberlin, S. A., \& Pereira, N. (2017). Differentiating engineering activities for use in a mathematics setting. In D. Dailey \& A. Cotabish (Eds.), Engineering Instruction for High-Ability Learners in K-8 Classrooms (pp. 45-55). Waco, TX: Prufrock Press.

Christenson, J. (2011). Ramaley coined STEM term now used nationwide. Winona Daily News. Retrieved from http://www.winonadailynews.com/news/local/ article_457afe3e-0db3-11e1-abe0-001cc4c03286.html

Clark, R., \& Andrews, J. (2010). Researching primary engineering education: UK perspectives, an exploratory study. European Journal of Engineering Education, 35(5), 585-595. https://doi.org/10.1080/03043797.2010.497551.

Dare, E. A., Ellis, J. A., \& Roehrig, G. H. (2014). Driven by beliefs: understanding challenges physical science teachers face when integrating engineering and physics. Journal of Pre-College Engineering Education Research, 4(2), 47-61. https://doi.org/10.7771/2157-9288.1098.

El-Deghaidy, H., Mansour, N., Alzaghibi, M. \& Alhammad, K. (2017). Context of STEM integration in schools: views from in-service science teachers. EURASIA Journal of Mathematics, Science, and Technology Education, 13(6), 2459-2484. https://doi.org/10.12973/eurasia.2017.01235a.

Gagné, F. (2007). Ten commandments for academic talent development. The Gifted Child Quarterly, 51, 93-118. https://doi.org/10.1177/0016986206296660.

Gagné, F. (2011). Academic talent development and the equity issue in gifted education. Talent Development and Excellence, 3(1), 3-22 http://d-nb.info/ $1011435659 / 34$.

Gomez, A., \& Albrecht, B. (2013). True STEM education. Technology and Engineering Teacher, 73(4), 8 Retrieved from https://www.teea.org/39191.aspx. Goodpaster, K. P. S., Adedokun, O. A., \& Weaver, G. C. (2012). Teachers' perceptions of rural STEM teaching: implications for rural teacher retention. Rural Educator, 33(3), 9-22. Retrieved from https://pdfs.semanticscholar.org/ 950f/3fe943ee93114431d09a56ffb61e1 b665778.pdf 
Haddaway, N. R., Collins, A. M., Coughlin, D., \& Kirk, S. (2015). The role of google scholar in evidence reviews and its applicability to grey literature searching. PLoS One, 10(9). https://doi.org/10.1371/journal.pone.0138237.

Herro, D. \& Quigley, C. (2017). Exploring teachers' perceptions of STEAM teaching through professional development: implications for teacher educators. Professional Development in Education, 43, 416-438. https://doi.org/10.1080/ 19415257.2016.1205507.

Hockett, J. A. (2009). Curriculum for highly able learners that conforms to general education and gifted education quality indicators. Journal for the Education of the Gifted, 32(3), 394-440. https://doi.org/10.4219/jeg-2009-857.

Holstein, K. A., \& Keene, K. A. (2013). The complexities and challenges associated with the implementation of a STEM curriculum. Teacher Education and Practice, 4, 616-636. Retrieved from https://journals.rowman.com

Honey, M., Pearson, G., \& Schweingruber, H. (2014). STEM Integration in K-12 Education: Status, Prospects, and an Agenda for Research (pdf version). https:// doi.org/10.17226/18612

Hsu, M. C., Purzer, S., \& Cardella, M. E. (2011). Elementary teachers' views about teaching design, engineering, and technology. Journal of Pre-College Engineering Education Research, 1(2), 31-39. https://doi.org/10.5703/ 1288284314639.

Johnson, C. C. (2006). Effective professional development and change in practice: barriers teachers encounter and implications for reform. Schoo/ Science and Mathematics, 106(3), 1-26. https://doi.org/10.1111/j.1949-8594.2006.tb18172.x.

Lehman, J. D., Kim, W., \& Harris, C. (2014). Collaborations in a community of practice working to integrate engineering design in elementary science education. Journal of STEM Education: Innovations and Research, 15(3), 21-28. Retrieved from http://jstem.org/

Lesseig, K., Slavit, D., Nelson, T. H., \& Seidel, R. A. (2016). Supporting middle school teachers' implementation of STEM design challenges. School Science and Mathematics, 116(4), 177-188. https://doi.org/10.1111/ssm.12172.

Liberati, A., Altman, D. G., Tetzlaff, J., Mulrow, C., Gøtzsche, P. C., loannidis, J. P., et al. (2009). The PRISMA statement for reporting systematic reviews and metaanalyses of studies that evaluate health care interventions: explanation and elaboration. Journal of Clinical Epidemiology, 62, 1-34. https://doi.org/10.1016/ j.jclinepi.2009.06.006.

MacFarlane, B. (2016). Infrastructure of comprehensive STEM programming for advanced learners. In B. MacFarlane (Ed.), STEM Education for High-Ability Learners Designing and Implementing Programming (pp. 139-160). Waco, TX: Prufrock Press.

Mann, E. L., \& Mann, R. L. (2017). Engineering design and gifted pedagogy. In D. Dailey \& A. Cotabish (Eds.), Engineering Instruction for High-Ability Learners in K-8 Classrooms (pp. 33-44). Waco, TX: Prufrock Press.

McHugh, M. L. (2012). Interrater reliability: the kappa statistic. Biochemia Medica, 22(3), 276-282.

McMullin, K., \& Reeve, E. (2014). Identifying perceptions that contribute to the development of successful project lead the way pre-engineering programs in Utah. Journal of Technology Education, 26(1), 22-46. https://doi.org/10. 21061/jte.v26i1.a.2.

Mooney, M. A., \& Laubach, T. A. (2002). Adventure engineering: a design centered, inquiry based approach to middle grade science and mathematics education. Journal of Engineering Education, 91(3), 309-318. https://doi.org/10 1002/j.2168-9830.2002.tb00708.x.

Moore, T. J., Stohlmann, M. S., Wang, H. H., Tank, K. M., Glancy, A., \& Roehrig, G. H. (2014). Implementation and integration of engineering in K-12 STEM education. In J. Strobel, S. Purzer, \& M. Cardella (Eds.), Engineering in precollege settings: research into practice. Rotterdam: Sense Publishers.

Mullet, D. R. (2016). Catalysts of Women's Talent Development in STEM: A Systematic Review (Unpublished doctoral dissertation). Denton: University of North Texas.

Nadelson, L. S., Callahan, J., Pyke, P., Hay, A., Dance, M., \& Pfiester, J. (2013). Teacher STEM perception and preparation: inquiry-based STEM professional development for elementary teachers. The Journal of Educational Research, 106(2), 157-168. https://doi.org/10.1080/00220671.2012.667014.

Nadelson, L. S., \& Seifert, A. (2013). Perceptions, engagement, and practices of teachers seeking professional development in place-based integrated STEM. Teacher Education and Practice, 26(2), 242-265. Retrieved from https:// journals.rowman.com

Nadelson, L. S., Seifert, A., Moll, A. J., \& Coats, B. (2012). i-stem summer institute: an integrated approach to teacher professional development in stem. Journal of STEM Education: Innovations and Research, 13(2), 69-83. Retrieved from www.jstem.org

National Academy of Engineering (NAE) and National Research Council (NRC). (2014). STEM integration in K-12 education: status, prospects, and an agenda for research. In M. Honey, G. Pearson, \& H. Schweingruber (Eds.), Committee on K-12 engineering education. Washington, DC: National Academies Press.

National Research Council. (2013). Monitoring Progress Toward Successful K-12 STEM Education: A Nation Advancing? Washington, DC: The National Academies Press Retrieved from https://www.nap.edu/download/13509\#.

National Science Board. (2007). A national action plan for addressing the critical needs of the U.S. science, technology, engineering, and mathematics education system. Washington, D. C: National Science Foundation.

National Science Board. (2012). Science and Engineering Indicators 2012 (NSB 1201). Arlington: National Science Foundation Retrieved from https://www.nsf. gov/statistics/seind12/pdf/overview.pdf.

Park, H., Byun, S., Sim, J., Han, H., \& Baek, Y. S. (2016). Teachers' perceptions and practices of STEAM education in South Korea. Eurasia Journal of Mathematics, Science, \& Technology Education, 12(7), 1739-1753. https://doi.org/10.12973/ Eurasia.2016.1531a.

Park, M., Dimitrov, D. M., Patterson, L. G., \& Park, D. (2017). Early childhood teachers' beliefs about readiness for teaching science, technology, engineering, and mathematics. Journal of Early Childhood Research, 15, 275291. https://doi.org/10.1177/1476718X15614040.

Smith, K. L., Rayfield, J., \& McKim, B. R. (2015). Effective practices in STEM integration: describing teacher perceptions and instructional method use. Journal of Agricultural Education, 56(4), 182-201. https://doi.org/10.5032/jae. 2015.04183.

Srikoom, W., Hanuscin, D. L., \& Faikhamta, C. (2017). Perceptions of in-service teachers toward teaching STEM in Thailand. Asia-Pacific Forum on Science Learning and Teaching, 18(2), 1-23. Retrieved from: http://www.eduhk.hk/ apfslt/

Stohlmann, M., Moore, T. J., \& Roehrig, G. H. (2012). Considerations for teaching integrated STEM education. Journal of Pre-College Engineering Education Research, 2(1), Article 4. https://doi.org/10.5703/1288284314653

Tomlinson, C. A., \& Moon, T. R. (2013). Assessment and Student Success in a Differentiated Classroom. Alexandria: ASCD.

Van Haneghan, J. P., Pruet, S. A., Neal-Waltman, R., \& Harlan, J. M. (2015). Teacher beliefs about motivating and teaching students to carry out engineering design challenges: some initial data. Journal of Pre-College Engineering Education Research, 5(2), 1-9. https://doi.org/10.7771/2157-9288.1097.

VanTassel-Baska, J., \& Little, C. A. (2011). Content-based curriculum for high-ability learners. Waco, TX: Prufrock Press.

Wang, H. H., Moore, T. J., Roehrig, G. H., \& Park, M. S. (2011). STEM integration: teacher perceptions and practice. Journal of Pre-College Engineering Education Research, 1(2), 1-13. https://doi.org/10.5703/1288284314636.

\section{Submit your manuscript to a SpringerOpen ${ }^{\circ}$ journal and benefit from:}

- Convenient online submission

- Rigorous peer review

- Open access: articles freely available online

- High visibility within the field

- Retaining the copyright to your article

Submit your next manuscript at $>$ springeropen.com 